\title{
Survey of campylobacter, salmonella and mycoplasmas in house crows (Corvus splendens) in Malaysia
}

\begin{abstract}
House crows (Corvus splendens) in Selangor, Malaysia were examined for the presence of Campylobacter species, Salmonella species, Mycoplasma gallisepticum and Mycoplasma synoviae by serology, culture and pcr. For the detection of Campylobacter and Salmonella species swabs were taken either from the intestine or cloaca. For the detection of mycoplasmas, swabs were taken either from the choanal cleft or trachea for culture and pcr and serum samples were tested by the rapid serum agglutination (rsa) and monoclonal antibody-blocking elisa (mbelisa) for antibodies to $\mathrm{M}$ gallisepticum and $\mathrm{M}$ synoviae. For campylobacter, $25 \cdot 3$ per cent of the crows were positive by culture, and the species identified were Campylobacter jejuni and Campylobacter coli. No Salmonella species were isolated. Four of 24 swabs were positive for $\mathrm{M}$ gallisepticum dna but none gave positive results for $\mathrm{M}$ synoviae dna. No M gallisepticum or M synoviae antibodies were detected by rsa but 60 per cent of the sera gave positive reactions for $\mathrm{M}$ gallisepticum and 13 per cent gave positive reactions for M synoviae by mbelisa.
\end{abstract}

Keyword: House crows; Crows; Corvus splendens; Campylobacter species; Salmonella species; Mycoplasma gallisepticum; Mycoplasma synoviae. 